Karolina Vrban Zrinski

DOI: https://dx.doi.org/10.21857/yq32oh2kw9 Izvorni znanstveni članak

Rukopis prihvaćen za tisak: 11.12.2019.

\title{
LINGVOSTILISTIČKA USPOREDBA ŠTOKAVSKE I KAJKAVSKE SVETE ROŽALIJE
}

\begin{abstract}
Sažetak
Ivan Krizmanić preveo je Svetu Rožaliju Antuna Kanižlića 1831. godine sa štokavskoga na kajkavski služeći se prvim Kanižlićevim izdanjem Svete Rožalije koje je tiskano u Beču 1780. godine. U lingvostilističkoj analizi opisujemo stilističke postupke redom kako se pojavljuju u izvorniku i prijevodu, zatim redom kako se pojavljuju za svaki pojedini primjer. Analizirali smo stilističke postupke koje nalazimo u prijevodu, ali ih ne nalazimo u izvorniku ili je u izvorniku odabran drugačiji stilistički postupak. Lingvostilistička analiza pokazala je različitost u stilističkim postupcima prijevoda u odnosu na izvornik. Izdvojeni su samo učestali stilistički postupci, primjerice opkoračenje, jako mjesto, inverzija, deminutivi, semantostilemi, ponavljanja, gradacija, asonanca, aliteracija i retoričko pitanje. Krizmanić je u pojedinim stihovima zbog izbora riječi promijenio smisao. Kako bi pak očuvao izvornu misao, u pojedinim stihovima bira riječi koje ne nalazimo kod Kanižlića.
\end{abstract}

Ključne riječi: Antun Kanižlić; Ivan Krizmanić; Sveta Rožalija; lingvostilistička analiza.

\section{Uvod}

Ivan Krizmanić (1766. - 1852.) bio je bistrički župnik, a njegov je književni rad uglavnom prevoditeljski, osim tri putopisa i drugih manjih književnih radova. Prevodio je na njemački i na hrvatski jezik (štokavski i kajkavski). Na njemački je jezik prevodio s engleskoga i hrvatskoga jezika, dok je na hrvatski jezik prevodio s njemačkoga, latinskoga i engleskoga jezika. Sa štokavskoga je na kajkavski preveo Osmanšćicu Tomka Mrnavića i Svetu Rožaliju Antuna Kanižlića.

Kanižlićevu Svetu Rožaliju preveo je 1831. godine sa štokavskoga na kajkavski, a ubrzo zatim i na njemački jezik. Točno se vrijeme nastanka njemačkoga prijevoda ne zna jer je izgubljena naslovna stranica toga prijevoda, ali se zna da je kajkavski prijevod stariji jer u njemačkom prijevodu spominje svoj hrvatski (kajkavski) prijevod (Dukat, 2002: 40). Kod kajkavskoga se prijevoda Krizmanić služio prvim Kanižliće- 
vim izdanjem Svete Rožalije koje je tiskano u Beču 1780. godine. Točan je naziv kajkavskoga prijevoda Sveta Rožalija Panormitanska Devica skinčena i spisana po Antonu Kanižliču Požežanu. Prijevod je nastao u Beču 1831. godine, ima 3.706 stihova ispjevanih u dvanaestercu trohejskoga ritma, ali možemo pronaći i pokoju nedosljednost u ritmu i broju slogova u stihu. Izvornik je napisan slavonskom štokavskom ikavicom, dvostruko rimovanim dvanaestercem trohejskoga ritma, što znači da je rima u sredini i na kraju stiha, dok je u prijevodu rima samo na kraju stiha.

Krizmanić je u svom prijevodu dopisao predgovor (Kanižlićeva Sveta Rožalija nema predgovor) s namjerom da čitatelju približi i objasni povijesni kontekst razdoblja u kojem je živjela sv. Rožalija, zatim je napisao i dodatak na kraju te šest redaka ispravaka. „Riječ je o stranici i stihovima gdje se upućuje na mjesece u godini koji bi trebali u spomenutim stihovima biti (po redu)“ (Jembrih, 2003: 233).

Kanižlićeva Sveta Rožalija najljepše je djelo hrvatskoga književnoga baroka i najznačajnije djelo katoličke obnove u sjevernoj Hrvatskoj. Uzimajući to u obzir, valja imati na pameti da su izražajna sredstva u jeziku izvornika bogata i nose stilističku vrijednost. Pišući o istraživanjima i problematici jezika starije hrvatske književnosti, Vončina (1977: 7) ističe da iz tih radova uglavnom doznajemo razvoj fonološkoga i morfološkoga sustava toga jezika. Kanižlićeva i Krizmanićeva Sveta Rožalija pisane su u dva autonomna jezična sustava s obzirom na leksik i sintaksu, stoga je lingvističko-stilistička analiza pogodna za usporedbu izvornika i prijevoda. Lingvističku stilistiku možemo opisati s obzirom na jezičnu razinu na kojoj se ostvaruje pojedini stilistički postupak, tako da se govori o fonostilistici (asonanca, aliteracija, rima, pjesnički homofoni), morfostilistici (deminutivi, augmentativi), semantostilistici (semantostilemi - riječi u prenesenom značenju) i sintaktostilistici (inverzija, distorzija, elipsa, opkoračenje), dok su jedinice stilskoga izražavanja stilemi koji mogu biti fonostilemi, morfostilemi, semantostilemi i sintaktostilemi (Vuletić, 2006).

\section{Postupak}

Dosadašnja se istraživanja jezika starije hrvatske književnosti mahom odnose na dva pristupa proučavanju. Prvi je pristup dijalektološki, u kojemu prevladava, ili je prevladavalo, uvjerenje da je jezik starih hrvatskih pisaca vrijedan proučavanja i jezičnih analiza samo ako se to uzima kao potvrda stanja pojedinoga dijalekta u prošlosti. Drugi je pristup diferencijalni, odnosno pristup kojim se nastoje objasniti one jezične činjenice koje nisu u skladu sa suvremenim književnim jezikom (Vončina, 1977: 7). U ovomu je radu analiza napravljena uspoređivanjem Svete Rožalije Antuna Kanižlića koju je izdala Slavonica iz Vinkovaca 1994. godine i prijevoda na kajkavski jezik Ivana Krizmanića Sveta Rožalija: Panormitanska Devica skinčena i spisana po Antonu Kanižliću Požežanu nastala u Beču iz 1831. godine, a prema rukopisu 
iz Nacionalne i sveučilišne knjižnice u Zagrebu. Kajkavski je prijevod na današnju hrvatsku latiničku grafiju transkribirao Alojz Jembrih. U radu donosimo primjere iz transkribiranoga prijevoda koji je objavljen u časopisu „Hrvatsko zagorje“, u dijelu Iz kajkavske književno-jezične baštine 2003. godine pod naslovom Krizmanićeva Sv. Rožalija (1830.). Krizmanićeva je Sveta Rožalija dopreporodna, stoga je pisana bez dijakritičkih znakova.

Bitno je naglasiti da je transkribiran samo dio Krizmanićeva kajkavskoga prijevoda, i to iz prvoga dijela 1. i 5. ulomak, a iz drugoga dijela 9., 11. i 12. ulomak. Stihovi koje smo analizirali najvećim su dijelom iz prvoga dijela i 1 . ulomka, zatim 5. ulomka i iz drugoga dijela iz 11. ulomka. Za analizu su bili traženi s jedne strane oni stihovi koji su se po svojim stilističkim obilježjima razlikovali od izvornika (Kanižlićeve Svete Rožalije), a s druge pak strane stihovi koji su bili reprezentativni primjeri pojedinih stilističkih postupaka.

\section{Analiza - Lingvostilistički postupci}

U lingvističko-stilističkoj analizi opisujemo stilističke postupke redom kako se pojavljuju u izvorniku i prijevodu, zatim redom kako se pojavljuju u svakom pojedinom primjeru. Analizirali smo stilističke postupke koji se pojavlju u prijevodu, ali ih ne nalazimo u izvorniku ili je u izvorniku odabran drugi stilistički postupak. Slijedi osam odabranih primjera koji zorno prikazuju kako izbor pojedinih jezičnih sredstava stvara stilističku vrijednost izraza.

Prvi dio, I.

Rožalija knjigi put čestituje. (Kanižlić)

Rožalija kamo tebe šalje tvoja,

Uzdisana, tamo putuj, knjigo moja.

Rožalija želi listu srečen put. (Krizmanić)

Želno čakan list! Kam tvoja te odpravlja

Rožalija, tam put tvoj naj zabavlja.

Želno čakan list! Početak Svete Rožalije u prijevodu Ivana Krizmanića možemo analizirati kao svojevrsni stilski optativ. Uskličnik se pak u lingvističko-stilističkoj analizi ne iščitava samo kao interpunkcijski znak nego i kao znak koji nosi povećanu emotivnu angažiranost. Prenošenjem u idući stih riječi Rožalija dobivamo opkoračenje, čija je funkcija isticanje te riječi, odnosno isticanje je postignuto stilskom figurom, a ne samom pozicijom u stihu kao što je to kod Kanižlića, koji započinje svoj spjev riječju Rožalija. Isticanje Rožalije u Krizmanićevu prijevodu ostvareno je, uz opkoračenje, interpunkcijskim znakom i pozicijom na jakom mjestu. Termin jako mjesto označava poziciju na kojoj je smještena pojedina riječ ili fraza. U retoričkom 
smislu jakim se mjesto smatra početak ili kraj koji se može odnositi na rečenicu, stih, strofu, pjesmu, priču, govor itd. Izričaj koji se stavlja na jako mjesto dobiva osobit značaj ili jednostavno postaje istaknut. Prenošenjem u novi stih (opkoračenje), jakim mjestom (početak stiha) i interpunkcijskim znakom (zarez koji odvaja) postignuto je trostruko stilsko isticanje Rožalije.

Prvi dio, I.

Nek on, draga brigo moja, tebe vodi. (Kanižlić)

Ljubljena skerb moja! On tebe naj vodi! (Krizmanić)

Za oblakšat svoje brige tužno brime. (Kanižlić)

Da si zlehkosti breme skerbi svoje. (Krizmanić)

U drugom primjeru u Krizmanićevu prijevodu ponovno nalazimo interpunkcijski znak uskličnik kao stilsko sredstvo u funkciji pojačavanja emotivne angažiranosti i isticanja fraze ljubljena skerb (draga briga) stavljanjem na početak stiha. Krizmanić često radi inverzije u odnosu na Kanižlićev spjev da bi ostvario rimu i ritam. Primjerice svoje brige tužno brime (Kanižlić) / breme skerbi svoje (Krizmanić). Obrnutim poretkom riječi ostvaruje se i poetičnost i rima, dok u retoričkom smislu izmijenjen poredak riječi može izraz približiti govornom stilu. Mogli bismo reći da je tada inverzija posljedica toka misli, a ne samo odstupanje od gramatičkoga ustrojstva rečenice.

Prvi dio, I.

Nek ti roseć sitna kiša zrak prohladi. (Kanižlić)

Tam rosni dežđek zraka ti naj prohladi. (Krizmanić)

I jug s kišom dune, ne bila ti duga. (Kanižlić)

Takva ti kiša naj ne bude preduga. (Krizmanić)

Bitno su obilježje Krizmanićeva kajkavskoga prijevoda koje nalazimo u cijelom spjevu deminutivi. Deminutivi, kao i augmentativi, obično se navode kao prirodna stilistička sredstva. Njihova je stilistička vrijednost sadržana u obliku. Oni mogu izgubiti svoju stilističku vrijednost tako da se više ne doživljavaju kao deminutivi i augmentativi već nose svoj logički sadržaj (Vuletić, 2006). U našem odabranom primjeru riječ kiša kod Kanižlića i kod Krizmanića ostaje u svom logičkom sadržaju i stilistički neutralnom obliku, dok Krizmanić sitnu kišu prevodi kao rosni dežđek. U tom kontekstu rosni dežđek kao deminutiv čuva svoju stilističku vrijednost i postaje emotivno obojena fraza. Krizmanić u svom prijevodu bira inačice iste riječi koje tada poprimaju tri razine značenja, od neutralnoga, kajkavskoga pa do stilističkoga izričaja (primjerice knjiga, list, listek). 
Prvi dio, I.

Ona njega slidi i s pameću prati,

Od brige problidi sva, jerbo je mati. (Kanižlić)

Sercem ga sprevađajuč, vsikud ga sledi,

I vsa, ar je mati, od skerbi pobledi. (Krizmanić)

Razlika u prijevodu u ovom je primjeru vidljiva na leksičkoj i na sintaktičkoj razini. Kanižlić je uporabio riječ pamet (pameću), dok Krizmanić bira riječ srce (sercem). To je semantostilistički postupak u kojem riječi nose prenesena ili dodatna značenja tako da riječ sercem u ovom primjeru postaje semantostilem. Obrnutim poretkom riječi u drugom stihu izraz ar je mati postaje umetak, zamjenom veznika $i$ zarezom kao i inverzijom u prvom stihu, Krizmanić je vrlo uspješno ostvario govornost stihova i približio stihove govornim izrazima.

Prvi dio, I.

Tko zna gdi je sada: na moru li, gdi li! (Kanižlić)

Na morju? Gde li je? Gdo zna, gde je sada? (Krizmanić)

Dva navedena stiha možemo čitati kao svojevrsni dijalog između Kanižlića i Krizmanića. Krizmanić u svom prijevodu trima pitanjima pojačava Kanižlićevo pitanje, stvara afektivno jake oblike i postiže ekspresivnost. Riječima gde, gdo, gde dobivamo aliteraciju glasa $\mathrm{g}$, dok se ponavljanjem podjednakih upitnih intonacijskih oblika (Gde li je? Gdo zna, gde je sada?). ostvaruje gradacija. Tri podjednaka intonacijska oblika nisu samo verbalno ponavljanje istoga sadržaja već su aspekt beskonačnoga trajanja (Vuletić, 2006). Osim toga, trima se uzastopnim prozodijski sličnim ili podjednakim oblicima ostvaruje pojačano ritmiziranje (Ivas, 1993).

Prvi dio, V.

Doć će dva nje sina, dva sokola siva. (Kanižlić)

Z nju dojdu dva sini, dva sokoli sivi. (Krizmanić)

Iz navedenoga primjera razvidno je da obojica autora ostvaruju asonancu i aliteraciju, Kanižlić (sina, sokola, siva), Krizmanić (sini, sokoli, sivi). Razliku pak možemo uočiti u fonometaforičkoj motiviranosti. Fonometaforička motiviranost govori o prenesenom smislu glasova (Vuletić, 2007: 160). Tako ćemo kod Kanižlića u asonanci pronalaziti samoglasnik a (a - izražava nešto veliko), a kod Krizmanića samoglasnik i (i - izražava nešto malo).

Drugi dio, XI.

Suzo moja, tko te, budući ja u miru, (Kanižlić)

Ah suza! Gdo te zleva? kad ja sem v miru, (Krizmanić) 
Zanimljiv je podatak da Krizmanić u Prvom dijelu Svete Rožalije ponavlja imperativ putuj, i to čak sedam puta, a uskličnik kao znak emotivne angažiranosti piše pet puta, i to na mjestima na kojima Kanižlić ne stavlja uskličnik. Emotivna angažiranost u Krizmanićevu prijevodu, osim već spomenutih emotivno obojenih riječi i interpunkcijskoga znaka, postignuta je uzvicima i vokativima, koji predstavljaju velika bogatstva govornoga sadržaja. Uzvik ah u navedenom primjeru znak je krajnjega afektivnoga izraza i nosi veliku stilističku vrijednost, osobito stoga što prethodi retoričkom pitanju (Gdo te zleva?) koje se ne nalazi u Kanižlićevu spjevu.

Prvi dio, I.

Ili snilazeći niz dol, u dol snišla,

Ili se vozeći rikom, riku prišla. (Kanižlić)

\section{Niz dol plazeči pazi, da dole zajdeš,}

Pregazi i potoka, ako ga najdeš. (Krizmanić)

Uz naš posljednji odabrani primjer donosimo kratak komentar Vladoja Dukata (2002), koji smatra da je Krizmanić u svom prijevodu promijenio smisao izvornika iz tehničkih razloga, zbog traženja rime i zgodnoga poretka riječi u stihu, ,.... da je prevodilac iz taštine htio posao svoj prikazati težim nego što je uistinu bio ili dajbudi trebao biti." (Dukat, 2002: 44). U našem primjeru jasno je vidljivo da se rika zamjenjuje potokom, ali ta zamjena nije nastala iz pukih tehničkih razloga i time promijenila izvornik već prevoditelj stavlja svoj prijevod i u prostorni kontekst. Taj se kontekst odnosi na bistrički kraj, u kojemu potok nosi denotativno značenje, a rika (rijeka) konotativno značenje. Denotacija i konotacija dva su osnovna načina značenja. Denotacija je osnovno značenje riječi bez dodatnih značenja, dok se konotacija odnosi na moguće dodatne sadržaje koji nose skup svih asocijacija, osobnih i emotivnih značenja vezanih uz tu riječ (Vuletić, 2007: 19). Iz svih navedenih primjera koje smo uspoređivali i analizirali u ovom radu, iz stilističkih i retoričkih postupaka koje je Krizmanić birao, a koje ne nalazimo kod Kanižlića, razvidno je da je Dukatov zaključak teško prihvatljiv. Naravno, pri tomu ne osporavamo jezične, književne i duhovne vrijednosti Kanižlićeve Svete Rožalije kao najznačajnijega djela katoličke obnove u sjevernoj Hrvatskoj.

\section{Zaključak}

Lingvističko-stilistička analiza pokazala je različitost u stilističkim postupcima prijevoda u odnosu na izvornik. Izdvojeni su samo učestali stilistički postupci koji su prikazani na odabranim primjerima, a to su opkoračenje, jako mjesto, interpunkcija, inverzija, deminutivi, semantostilemi, veznici, uzvici, ponavljanja, gradacija, asonanca, aliteracija i retoričko pitanje. Različitost stilističkih postupaka pridonijela 
je približavanju govornoj sredini kojoj Krizmanić pripada i kojoj je prijevod tada bio namijenjen. Istodobno Sveta Rožalija vjerno je i dobro prevedena.

O Krizmanićevu prijevodu Svete Rožalije Dukat (2002: 45) donosi sljedeći sud: „... Sv. je Rožalija inače vjerno prevedena. Tu i tamo prijevod je sasvijem jednak originalu, ili se dajbudi razlikuje samo toliko, koliko to iziskuje razlika dijalekata." Dodajmo tomu da su štokavska i kajkavska Sveta Rožalija dva autonomna jezična sustava s obzirom na leksik, sintaksu, ali i stilističke postupke (primjerice česta uporaba deminutiva u kajkavskom prijevodu). Jezični sustavi mogu biti slični, ali to ne umanjuje trud i uspjeh prevoditelja. Sličnost jezičnih sustava često može biti i otežavajući element jer se u prijevodu zrcali i sociolingvistička vjernost prijevoda, a ne samo vjernost prijevoda u odnosu na izvornik. Lingvostilistička usporedba Kanižlićeve i Krizmanićeve Svete Rožalije pokazuje neospornu književnu i jezičnu vrijednost kajkavskoga prijevoda, ali nas i iznova vraća na otkrivanje jezičnih vrijednosti i osobitosti štokavskoga izvornika.

\section{Literatura}

Dukat, Vladoje. 2002. Život i književni rad Ivana Krizmanića. Kajkaviana, Donja Stubica: Kajkaviana; Pregrada: Matis.

Ivas, Ivan. 1993. „Izričajna jezgra u hrvatskom jeziku“. Doktorska disertacija. Zagreb: Sveučilište u Zagrebu.

Jembrih, Alojz. 2003. „Krizmanićeva Sv. Rožalija (1830.)“. Iz kajkavske književno-jezične baštine, časopis za kulturu Hrvatsko zagorje: 231-249.

Kanižlić, Antun. 1994. Sveta Rožalija. Vinkovci: Slavonica.

Krizmanić, Ivan. 1831. Sveta Rožalija: Panormitanska Devica skinčena i spisana po Antonu Kanižliču Požežanu. Beč. (rukopis NSK)

Silić, Josip. 2006. Funkcionalni stilovi hrvatskoga jezika. Zagreb: Disput.

Vončina, Josip. 1977. Analize starih hrvatskih pisaca. Split: Čakavski sabor.

Vuletić, Branko. 2006. Govorna stilistika. Zagreb: FF press.

Vuletić, Branko. 2007. Lingvistika govora. Zagreb: FF press. 


\section{Linguo-stylistic Comparison of Štokavian and Kajkavian Long Poem Sveta Rožalija}

\section{Summary}

In 1831, Ivan Krizmanić translated Sveta Rožalija by Antun Kanižlić from Štokavian into Kajkavian, using thereby the first edition of Kanižlić's work, published in Vienna in 1780. In the linguo-stylistic analysis, the author first lists stylistic procedures as they are used in the original and in the translation, and then in the order in which they are used in every individual example. Analyzed are stylistic procedures used in the translation, but not found in the original, or a different stylistic procedure has been used in the original. The linguo-stylistic analysis has shown that different stylistic procedures have been used in the translation in comparison to those used in the original. Only the most frequently used stylistic procedures have been singled out: enjambement, stressed sections, inversion, diminutives, semanto-stylemes, repetitions, gradation, assonance, alliteration, and rhetorical question. Due to Krizmanićs choice of words, the meaning of certain verses has been changed. However, in order to preserve the original thought, in certain verses he chose words that are not found in Kanižlić's original work.

Keywords: Antun Kanižlić; Ivan Krizmanić; Sveta Rožalija; linguo-stylistic analysis.

Doc. dr. sc. Karolina Vrban Zrinski

Odsjek za kroatologiju

Fakultet hrvatskih studija Sveučilišta u Zagrebu

Borongajska cesta 83d, 10000 Zagreb

kvzrinski@hrstud.hr 